\title{
TIDAL EFFECTS ON ICHTHYOPLANKTON AGGREGATION AND DISPERSION IN THE SOUTHERN GULF OF MEXICO
}

\author{
María Adela Monreal Gómez $z^{1, *}$, David Alberto Salas de León ${ }^{l}$, Cesar Flores Coto ${ }^{l}$, Fernando Flores \\ Hernández ${ }^{1}$, David Salas Monreal ${ }^{2}$ and Mayra Lorena Riverón Enzástiga ${ }^{1}$ \\ ${ }^{1}$ Instituto de Ciencias del Mar y Limnología, Universidad Nacional Autónoma de México \\ (Circuito Exterior S/N, Ciudad Universitaria, México D.F., 04510, México) \\ ${ }^{2}$ Instituto de Ciencias Marinas y Pesquerías, Universidad Veracruzana \\ (Calle Hidalgo 617, Col. Río Jamapa, 94290 Boca del Río, Veracruz, México) \\ *Corresponding author: monreal@cmarl.unam.mx
}

\begin{abstract}
A B S T R A C T
The role of vertical barotropic and baroclinic tidal forcing in the aggregation and dispersion of ichthyoplankton in the Southern Gulf of Mexico was analyzed in this study. Samplings of ichthyoplankton and the determination of hydrographic parameters were performed during September 1992 at a single point of $180 \mathrm{~m}$ depth, near the shelf break $\left(19^{\circ} 32^{\prime} \mathrm{N}-92^{\circ} 38.5^{\prime} \mathrm{W}\right)$. A $24 \mathrm{~h}$ CTD yo-yoing casting and biological samples were taken every $2 \mathrm{~h}$ and these measurements were combined with water velocity and density simulations from the Regional Ocean Model System (ROMS). One thermocline and two haloclines were depicted. The Froude number increased with a 2 $\mathrm{h}$ lag with respect to the maximal barotropic tide, suggesting the existence of a baroclinic tide. Aggregation and dispersion of the ichthyoplankton showed vertical oscillations in the abundance and the numbers of taxa and larvae with a $5 \mathrm{~h}$ lag with respect to the maximal barotropic tide and were in phase with the thermocline oscillation. The vertical oscillation was attributed to a hydraulic control forced by the internal tide.
\end{abstract}

\section{RESUMO}

Este estudo analisou o papel das forçantes barotrópica e baroclínica das marés na agregação e dispersão do ictioplâncton no sul do Golfo do México. A amostragem do ictioplâncton e o cálculo dos parâmetros hidrográficos foram realizados durante Setembro de 1992 num ponto fixo de $180 \mathrm{~m}$ de profundidade, perto da quebra de plataforma $\left(19^{\circ} 32^{\prime} \mathrm{N}-92^{\circ} 38.5^{\prime} \mathrm{W}\right)$. Uma amostragem de tipo yoyo com CTD foi realizada durante $24 \mathrm{~h}$ e amostras biológicas foram tomadas a cada $2 \mathrm{~h}$. Estas medidas foram combinadas com dados de densidade da água e velocidade obtidas de simulações do modelo do Sistema Regional de Modelo dos Oceanos (ROMS). Uma termoclina e duas haloclinas foram detectadas. $\mathrm{O}$ número de Froude aumentou com uma defasagem de $2 \mathrm{~h}$ com relação à maré barotrópica, sugerindo a existência de uma maré baroclínica. A agregação e a dispersão do ictioplancton mostraram variações verticais tanto em abundância quanto no número de taxa e larvas, com defasagem de $5 \mathrm{~h}$ em relação à máxima maré barotrópica e esteve em fase com a oscilação da termoclina. A oscilação vertical foi atribuída a um controle hidráulico forçado pela maré interna.

Descriptors: Ichthyoplankton distribution, Internal tides, Internal waves, Bay of Campeche, Gulf of Mexico.

Descritores: Distribuição do ictioplâncton, Marés internas, Ondas internas, Baía de Campeche, Golfo do México.

\section{INTRODUCTION}

Previous studies suggest that the effects of internal waves on the distribution of plankton may extend throughout the entire water column (SANGRÁ INCIARTE et al., 2001; LENNERT CODY; FRANKS, 2002), thus providing evidence that the internal high-frequency non-linear wave is an important means of the physical forcing of the vertical transport and mixing of biogenic and non-biogenic components in the water column and hence in the distribution of zooplankton (LODER et al., 1992; DOWER; BRODEUR, 2004). The aggregation of zooplankton biomass occurs in areas of physical and topographical discontinuities, such as seamounts, canyons, and shelf breaks (GENIN, 2004; SALAS DE LEÓN et al., 2011), where internal wave formation has been observed (PICHON et al., 2013; GONZÁLEZ POLA et al., 2012). Long internal waves in the ocean are non-dispersive, therefore nonlinearities can deform and break them, producing 
internal hydraulic jumps (BAINES, 1986). The hydraulic jumps affect the mixing and dissipation process of the ocean, as well as the energy distribution among the internal modes (HOLLOWAY; MERRIFIELD, 1999), modulating the aggregation and dispersion of planktonic organisms (GENIN, 2004). The shelf edge region is an important mixing area and internal tides and waves are the physical mechanism for the cross-shelf transport of nutrients and larvae (PINEDA, 1999; SHANKS, 1983). It has been observed that when internal waves are well developed in the seasonal thermocline layer, the temperature and zooplankton biomass series exhibit coherent local peaks of spectral density at similar wavelengths (PIONTKOVSKI et al., 1997).

A complex topography might exert an important effect on the boundary mixing of the ocean (CARTER et al., 2008; HOLLOWAY; MERRIFIELD, 1999). The generation of internal tides at the shelf edge and their subsequent propagation is one of the processes that induce oceanic mixing (BAINES, 1986). Internal waves have a largeamplitude at the pycnocline depth, mainly induced by internal tides under special conditions of bottom topography (MUNROE; LAMB, 2005); during its propagation the induced disturbance may produce areas of convergence and strong currents (HEGGELUND et al., 2004; JOHNSON; ROCKLIFF, 1986; HILL; JOHNSON, 1974). Strong semidiurnal internal tides are observed near complex topographies such as abrupt escarpments (ALTHAUS et al., 2003; NASH et al., 2004; JOHNSTON; MERRIFIELD, 2003; HIBIYA, 2004).

The southeastern Bay of Campeche is bordered by a shallow continental shelf. The depth of this shelf is typically less than $200 \mathrm{~m}$. At the shelf edge, the depth increases from $200 \mathrm{~m}$ to $1000 \mathrm{~m}$ in less than $30 \mathrm{~km}$ (Fig. 1a,b), reaching more than 3000 $\mathrm{m}$ at the center of the bay. Despite this bathymetric gradient, the existence of internal tides has never been reported in the Southern Gulf of Mexico. Internal waves have been described for the northern gulf (RUBENSTEIN, 1999), but not in the southern gulf.

The aim of this study focuses the aggregation and dispersion of ichthyoplankton due to internal tides. The interaction of the barotropic tide with the shelf edge was analyzed in this study. This interaction induces a baroclinic tide which produces an internal semi-hydraulic jump in the southern Gulf of Mexico.

\section{Material and Methods}

\section{Study Site}

The study was undertaken in the southeastern Bay of Campeche (southern Gulf of Mexico) at a single point located at $19^{\circ} 32^{\prime} \mathrm{N}$ and $92^{\circ} 38.5^{\prime} \mathrm{W}$, where the total depth is of $180 \mathrm{~m}$ (Fig. 1a). This area is influenced by a coastal current from the Campeche shelf, and by the runoff from the Grijalva-Usumacinta river system that induces haline fronts (MONREAL GÓMEZ et al., 1992). A cyclonic eddy dominates the mesoscale circulation in the bay, combined with a pair of coastal cyclonic and anticyclonic eddies (SALAS DE LEÓN et al., 1998). The depth of the thermocline is influenced by the interaction between the mesoscale circulation and the shallow shelf break, resulting in a sharp thermocline due to the rise of the isotherms on the continental shelf (WALSH et al., 2003), which produces inertial oscillations (EXPÓSITO DÍAZ et al., 2009). The tides in the region (at the Del Carmen tide gauge, the nearest to the sampling point) are mixed, with diurnal dominance (SALAS DE LEÓN; MONREAL GÓMEZ, 1997).

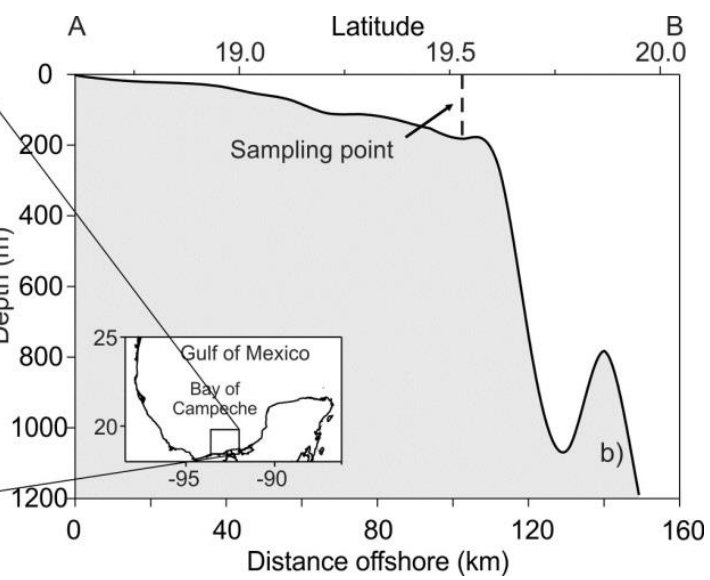

Fig. 1. a) Bathymetric (m) map of the study area showing the location of the sampling point and the del Carmen tide gauge, and b) the bathymetric profile along transect $\mathrm{AB}$. 
Ichthyoplankton that inhabit the continental shelf waters of the southern Gulf of Mexico are grouped into five assemblages: coastal, inner neritic, outer neritic, oceanic, and transition (FLORES COTO et al., 2000). The presence of the carangid Chloroscombrus chrysurus and the sciaenids Cynoscion arenarius, Menticirrhus spp., Micropogonias spp., and Stellifer lanceolatus characterize the coastal assemblage. The more frequent and abundant species in the oceanic assemblage are Bregmaceros atlanticus, Myctophum spp., Myctophum nitidulum, Hygophum macrochir, Benthosema suborbitale, Diaphus spp., Cyclothone spp., and Bregmaceros cantori. The main taxa characterizing the inner neritic assemblage are Selene setapinnis, Selar crumenophthalmus, Syacium gunteri, Bothus ocellatus, Bregmaceros cantori, and Trichiurus lepturus. The frequent and abundant species in the outer neritic assemblage are Diaphus spp., Cyclothone spp., Anthias spp., Thunnus spp., Selar crumenophthalmus, Caranx crysos, Trachurus lathami, Auxis rochei, and Bregmaceros cantori. The main taxa in the transition group are associated with inner neritic, outer neritic, and oceanic assemblages and include Caranx crysos, Selar crumenophthalmus, Bothus ocellatus, Selene setapinnis, Diaphus spp., and Ceratoscopelus warmingii (ESPINOSA FUENTES; FLORES COTO, 2004).

\section{Data Collection and Ichthyoplankton Sampling}

An oceanographic cruise was undertaken on September 13 and 14, 1992 to study the distribution and abundance of fish larvae on the edge of the continental shelf (Fig. 1b) in the southeastern Bay of Campeche (Southern Gulf of Mexico). The ichthyoplankton was sampled and the hydrographic parameters recorded every $2 \mathrm{~h}$ at a sampling point located at $19^{\circ} 32^{\prime} \mathrm{N}$ and $92^{\circ} 38.5^{\prime} \mathrm{W}$ (Campeche shelf break, southern Gulf of Mexico) (Fig. 1). The $24 \mathrm{~h}$ sampling started during the ebb phase (Fig. 2).

A Neil Brown Mark III CTD was used to record conductivity, temperature, and pressure from the surface to $180 \mathrm{~m}$ depth every two hours. Salinity and density $\left(\sigma_{t}\right)$ were calculated in accordance with the thermodynamic equation of seawater - 2010 (TEOS-10) algorithms (http://www.teos-10.org/). Consecutive vertical profiles of temperature, salinity, and density $\left(\sigma_{t}\right)$ were made, as well as their time series corresponding isolines, and Brunt-Väisälä frequency (buoyancy frequency) contours versus depth.

The ichthyoplankton was collected using a paired $60 \mathrm{~cm}$ diameter Bongo net with 333 and 505 $\mu \mathrm{m}$ mesh. The total filtered volume, during towing, was measured by pre-calibrated flow meters placed in the mouth of each net. The double oblique tows were made to a maximum depth of $170 \mathrm{~m}$, leaving $10 \mathrm{~m}$ of clearance so that the net did not hit the sea floor. The tow speed was of two knots $\left(\approx 1 \mathrm{~m} \mathrm{~s}^{-1}\right)$, the net was deployed at $1 \mathrm{~m} \mathrm{~s}^{-1}$, and it was recovered at $0.5 \mathrm{~m} \mathrm{~s}^{-1}$. The nets stayed at the maximum depth for one minute before recovery was started.

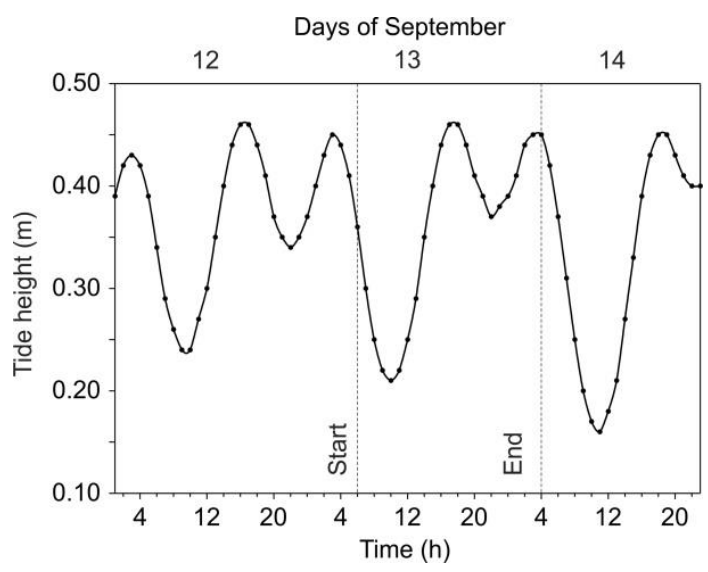

Fig. 2. Tidal height from 12-14 September 1992, at del Carmen tidal gauge, showing the start and end of the sampling period.

Samples were fixed in $4 \%$ formalin and transferred to $70 \%$ alcohol after $24 \mathrm{~h}$ for preservation. In the laboratory, all fish larvae were sorted from the $505 \mu \mathrm{m}$ mesh net and identified to genus or species level. Larval engraulid and gobiids were not considered in the analysis because the larvae of these two families cannot be reliably identified to genus or species level. Larval abundance was normalized to $100 \mathrm{~m}^{3}$ of water. For the purposes of Table 1, larvae were characterized as oceanic or neritic according to their adult habitat (FAHAY, 1983; YÁÑEZ ARANCIBIA; SÁNCHEZ GIL, 1986; ESPINOSA FUENTES; FLORES COTO, 2004).

The fish larvae abundance was estimated in terms of number of individuals per 100 cubic meters. Finally a graph of the total number of larvae per 100 $\mathrm{m}^{3}$ and taxa per $100 \mathrm{~m}^{3}$ with a $4 \mathrm{~h} \mathrm{lag}$, and barotropic tide height (m) vs. time (s) shows schematically the dependence of the total taxa and larvae on the barotropic tide, this latter dependence being corroborated by a Spearman rank correlation between the barotropic tide height $(\mathrm{m})$ and the total number of larvae per $100 \mathrm{~m}^{3}$ detrended series. The $4 \mathrm{~h} \mathrm{lag}$ is allowed because of the time taken for the transfer of the energy of the $\mathrm{M}_{2}$ barotropic-to-baroclinic tidal conversion at the shelf break. 
Table 1. Ichthyoplankton abundance $\left(\times 100 \mathrm{~m}^{3}\right)$ by taxon and time $(\mathrm{h}) . \mathrm{N}$ : neritic; O: oceanic.

\begin{tabular}{|c|c|c|c|c|c|c|c|c|c|c|c|c|c|}
\hline & & & & & & & Time (h) & & & & & & \\
\hline & & 6 & 8 & 10 & 12 & 14 & 16 & 18 & 20 & 22 & 0 & 2 & 4 \\
\hline Pisodonophis spp & $\mathrm{N}$ & & 0.67 & 0.63 & & & & & 1.16 & 0.59 & & & \\
\hline Bathylagus spp & $\mathrm{O}$ & & & & 0.75 & & & & & 0.59 & & & \\
\hline Cyclothone braueri & $\mathrm{O}$ & & 0.67 & & 0.75 & & & & 0.58 & 1.76 & 2.24 & & \\
\hline Maurolicus muelleri & $\mathrm{O}$ & & 1.88 & & 6.76 & & & & 2.91 & 3.53 & 2.81 & 5.20 & 3.78 \\
\hline Gonostoma elongatum & $\mathrm{O}$ & & & & & & 0.66 & & & & 0.56 & & \\
\hline Pollichthys mauli & $\mathrm{O}$ & & & & & & & & 1.16 & 2.35 & 0.56 & & \\
\hline Synodus foetens & $\mathrm{N}$ & 4.01 & 3.36 & 6.91 & 0.75 & & 0.66 & 3.57 & 13.95 & 16.47 & 19.64 & 13.65 & 8.81 \\
\hline Trachinocephalus myops & $\mathrm{N}$ & & & & & & & & 0.58 & & 0.56 & & \\
\hline Notolepis rissoi & $\mathrm{O}$ & & & & 0.75 & & & & & & & & 1.26 \\
\hline Scopelarchus analis & $\mathrm{O}$ & & & & & & & & & & 1.12 & & 1.26 \\
\hline Diaphus spp & $\mathrm{O}$ & & & & 1.50 & & 1.32 & & 1.74 & 2.94 & 2.24 & 0.65 & 0.63 \\
\hline Benthosema suborbitale & $\mathrm{O}$ & 3.43 & 1.34 & 3.14 & & & 0.66 & 1.43 & 0.58 & 0.59 & 1.12 & 3.90 & 6.92 \\
\hline Notolichnus valdiviae & $\mathrm{O}$ & & & & & & & 0.71 & & & & & 1.26 \\
\hline Myctophum nitidulum & $\mathrm{O}$ & & 2.69 & & & & & & 1.74 & & & 2.60 & \\
\hline Myctophum obtusirostre & $\mathrm{O}$ & & 0.67 & & & & & & & & & & \\
\hline Myctophum punctatum & $\mathrm{O}$ & & & & 1.50 & & & & & & 1.12 & & 1.89 \\
\hline Hygophum taaningi & $\mathrm{O}$ & & & 0.63 & & & & & & & 0.56 & & \\
\hline Hygophum macrochir & $\mathrm{O}$ & & & & & & & & & & 0.56 & & \\
\hline Hygophum hygomii & $\mathrm{O}$ & & & 3.14 & 2.25 & & & 7.14 & & 1.18 & & & \\
\hline Diogenichthys atlanticus & $\mathrm{O}$ & & & 0.63 & 2.25 & & 0.66 & & & 1.18 & & & \\
\hline Ceratoscopelus maderensis & $\mathrm{O}$ & 1.14 & 1.34 & & 4.51 & & 2.63 & 1.43 & 1.74 & 2.35 & 1.12 & & 5.03 \\
\hline Bregmaceros atlanticus & $\mathrm{O}$ & & & 1.88 & 1.50 & & & & 1.16 & 2.35 & 0.56 & 0.65 & \\
\hline Bregmaceros cantori & $\mathrm{O}$ & 5.15 & 10.08 & 12.56 & 19.53 & 2.67 & 13.80 & 12.13 & 9.30 & 12.94 & 21.32 & 10.40 & 13.85 \\
\hline Bregmaceros macclellandi & $\mathrm{O}$ & & & & & & & & 0.58 & & & & \\
\hline Bregmaceros $\mathrm{sp}$ & $\mathrm{O}$ & & & & & & & & 0.58 & & & & \\
\hline Sygnathus sp & $\mathrm{N}$ & & & & & & & 0.71 & & & & & \\
\hline Scorpaena spp & $\mathrm{N}$ & & & & & & 0.66 & & & & 0.56 & & \\
\hline Scorpaenodes spp & $\mathrm{N}$ & & & & 0.75 & & & & & & & & \\
\hline Serranus spp & $\mathrm{N}$ & & & 1.26 & & & & 1.43 & & 0.59 & & & \\
\hline Centropristis spp & $\mathrm{N}$ & & & & & & & & & 0.59 & & & \\
\hline Diplectrum spp & $\mathrm{N}$ & & & & & & & & & & 1.12 & & \\
\hline Chloroscombrus chrysurus & $\mathrm{N}$ & 1.14 & 1.34 & 1.26 & 0.75 & & & & 1.16 & 0.59 & & 0.65 & 2.52 \\
\hline Decapterus punctatus & $\mathrm{O}$ & & & & & & & 0.71 & & & 0.56 & & \\
\hline Selar crumenophthalmus & $\mathrm{N}$ & & & & & & & 0.71 & & & 0.56 & 0.65 & \\
\hline Selene spixii & $\mathrm{N}$ & & & & & & & & & & 2.81 & 0.65 & \\
\hline Selene setapinnis & $\mathrm{N}$ & & & & & & 0.66 & & & & & 0.65 & 1.26 \\
\hline Gerres spp & $\mathrm{N}$ & & & & & & & & & 0.59 & & & \\
\hline Mugil cephalus & $\mathrm{N}$ & & & & & & & & & & 1.12 & & 1.26 \\
\hline Microdesmus spp & $\mathrm{N}$ & & & & & & & & 1.16 & & & & \\
\hline Diplospinus spp & $\mathrm{N}$ & & & & & & & & & 0.59 & & & \\
\hline Diplospinus multistriatus & $\mathrm{N}$ & & 0.67 & & 0.75 & & & & 0.58 & & & & \\
\hline Thunnus albacares & $\mathrm{O}$ & & & & 0.75 & & & & & & & & \\
\hline Scomber japonicus & $\mathrm{O}$ & & 0.67 & & & & & & & & & & \\
\hline Scomberomorus cavalla & $\mathrm{O}$ & & & & & & & & 2.91 & 0.59 & & 0.65 & 1.26 \\
\hline Bothus ocellatus & $\mathrm{N}$ & 0.57 & 1.34 & 0.63 & 3.76 & & 1.31 & 2.14 & 2.32 & 0.59 & 1.12 & & 1.26 \\
\hline Citharichthys spp & $\mathrm{N}$ & & & 0.63 & & & & & 0.58 & & & & \\
\hline Syacium gunteri & $\mathrm{N}$ & & 4.70 & 7.54 & 4.51 & & 1.97 & 2.86 & 12.20 & 9.41 & 12.35 & 7.80 & 3.78 \\
\hline Engyophrys spp & $\mathrm{N}$ & & & & & & & & & & & 0.65 & \\
\hline Etropus spp & $\mathrm{N}$ & & & 5.03 & & & & 2.86 & 2.32 & & & & \\
\hline Cyclopsetta fimbriata & $\mathrm{N}$ & & & & 0.75 & & & 0.71 & & & & & \\
\hline Symphurus spp & $\mathrm{N}$ & & & & & 2.67 & 0.66 & 2.86 & 5.81 & 10.59 & & & \\
\hline Symphurus plagiusa & $\mathrm{N}$ & 2.86 & 9.41 & 1.26 & 6.01 & & & & & & 8.98 & 9.75 & 6.92 \\
\hline Monacanthus hispidus & $\mathrm{N}$ & & & & & & & & & & & & 0.63 \\
\hline
\end{tabular}

Model Setup

The Regional Ocean Model System (ROMS) has been used to model internal tides and to estimate tidal fields for studying circulation and mixing. According to Robertson (2006), the semidiurnal baroclinic tides are well simulated with ROMS. In this study the ROMS was set up following Moore et al. 
(2004). For more information on the model see Salas Monreal et al. (2012).

The model outputs were used to describe the dynamics of an idealized generic system similar to the one located near the Bay of Campeche shelf break. The three-dimensional primitive equations ocean model uses $\sigma$ coordinates to increase the vertical resolution at the depth of the internal wave (MOORE et al., 2004). The model simulates a $2000 \mathrm{~m}$ depth slope with a horizontal domain of $30 \times 30 \mathrm{~km}$ alongshore and offshore, with 20 variable vertical levels and a maximal vertical resolution of $125 \mathrm{~m}$. The free surface elevation, which uses a non-gradient open boundary condition and the salinity, temperature, and water velocities at each grid point were recorded over a $2 \mathrm{~h}$ period after the model had reached stability. Bottom stress was assumed to be a quadratic function of the bottom velocity with a drag coefficient of $2.5 \times$ $10^{-3}$. The model started from a steady state with a uniform horizontal salinity and temperature field and a vertical step stratification of $1024 \mathrm{~kg} \mathrm{~m}^{-3}$ at surface and $1027 \mathrm{~kg} \mathrm{~m}^{-3}$ at the bottom (MONREAL GÓMEZ et al., 1992). The boundary conditions were obtained using data from the ADCP (SALAS DE LEÓN et al., 2004) and with tidal amplitude and phase obtained from Salas de León and Monreal Gómez (1997). The potential and kinetic energy were calculated for each grid point. The stability of the model was analyzed using potential and kinetic energy. Once the differences in energies from successive iterations were of the order of $10^{-3}$ or lower, the model was considered to be stable; this occurred after 8 days of simulations. Although the ROMS is a non-hydrostatic model (OEY et al., 2010; LAI et al., 2010), the velocities obtained here were used to compare the inertial versus gravitational forces (Froude number).

The model does not account directly for zooplankton concentration because it does not contain any type of ecosystem model. However, it is assumed that over irregular bathymetries, planktonic organisms are concentrated at the pycnocline depth (ZELDIS; JILLETT, 1982; SHANKS, 1983; LENNERT CODY; FRANKS, 1999; RYAN et al., 2005).

Although planktonic organisms are biologically active, there are similarities between the diffusion of salinity and the plankton advection (VALLE LEVINSON et al., 2004). However, zooplankton can cross the pycnocline depending on the hour of the day and the state of turbulence of the water (HEYWOOD, 1996, BERGSTRÖM; STRÖMBERG, 1997).

\section{RESULTS}

Temperature, salinity, and density $\left(\sigma_{t}\right)$ profiles (Fig. 3) showed an approximately $15 \mathrm{~m}$ rise of the thermocline in $6 \mathrm{~h}$ (Fig. 3a). Vertical structure of salinity showed a double halocline (Fig. 3b), a pattern also shown by density $\left(\sigma_{t}\right)$ (Fig. $3 \mathrm{c}$ ), indicating that density is governed by salinity. One thermocline and two haloclines were observed. The thermocline and the lower halocline and pycnocline rose by approximately $15 \mathrm{~m}$. The upper halocline and pycnocline presented no change in depth at any time during the sampling period, indicating that the effect of vertical variation is internal. The distribution of temperature, salinity, density $\left(\sigma_{t}\right)$, and the BruntVäisälä or buoyancy frequency against depth and time (Fig. 4) showed a rising of the isolines between 8 and $12 \mathrm{~h}$, particularly in salinity and density $\left(\sigma_{t}\right)$. The absolute maxima of the Brunt-Väisälä frequency were shallower at $12 \mathrm{~h}$, becoming deeper thereafter. The internal Froude number $\left(F_{r}^{\prime}\right)$, i.e. the square root of the ratio of the internal force to the buoyancy force for baroclinic motions in a stratified fluid (Fig. 5), was almost always greater than 2 , indicating that the flow was supercritical (LODER et al., 1992), i.e., fast moving but without reaching the excessive turbulence that can produce instability. At $12 \mathrm{~h}$ it diminished to 1.5 indicating an increase in turbulence.
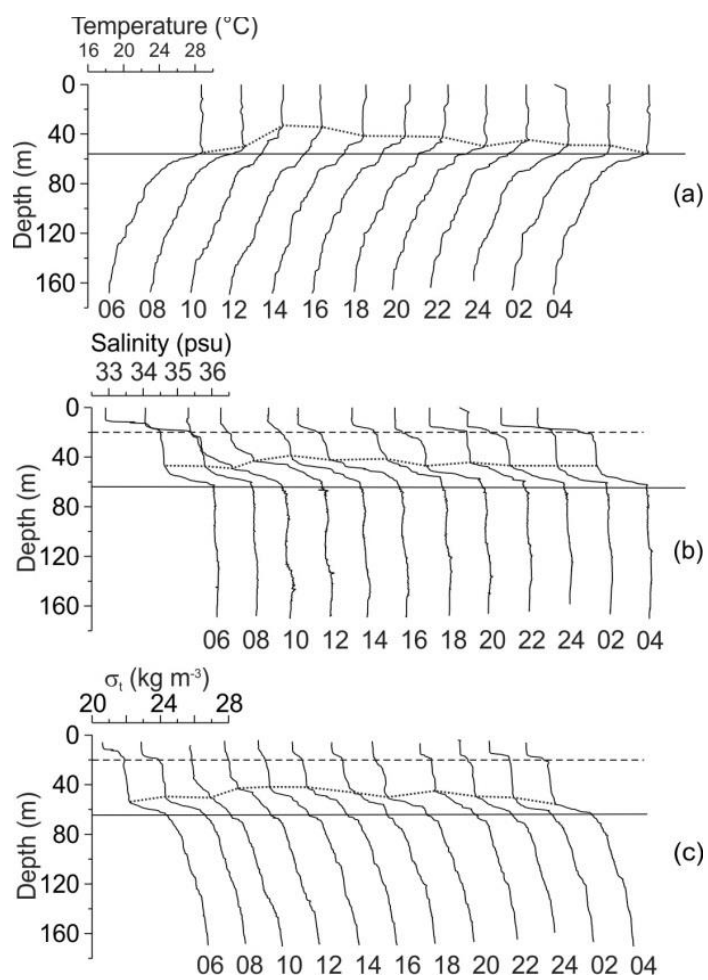

Fig. 3. Consecutive vertical profiles of: a) temperature $\left({ }^{\circ} \mathrm{C}\right)$, b) salinity, and c) density $\left(\sigma_{\mathrm{t}}\right)\left(\mathrm{kg} \mathrm{m}^{-3}\right)$. 


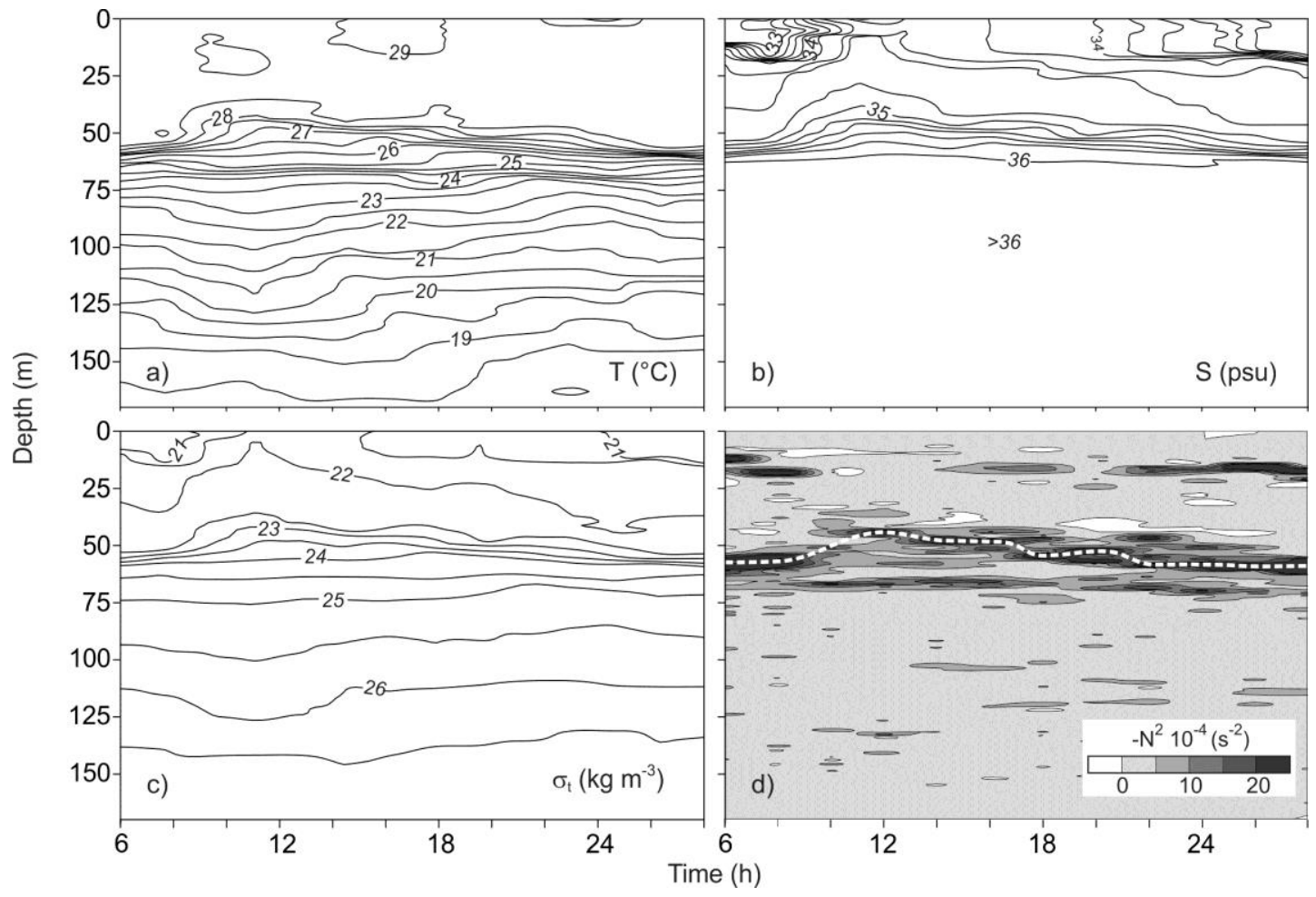

Fig. 4. Time series at different depths at sampling point: a) Temperature $\left({ }^{\circ} \mathrm{C}\right)$, b) salinity $(S)$, c $)$ density $\left(\sigma_{t}\right)\left(\mathrm{kg} \mathrm{m}^{-3}\right)$, and d) square of the Brunt-Väisälä frequency $\left(\mathrm{s}^{-2}\right)$.

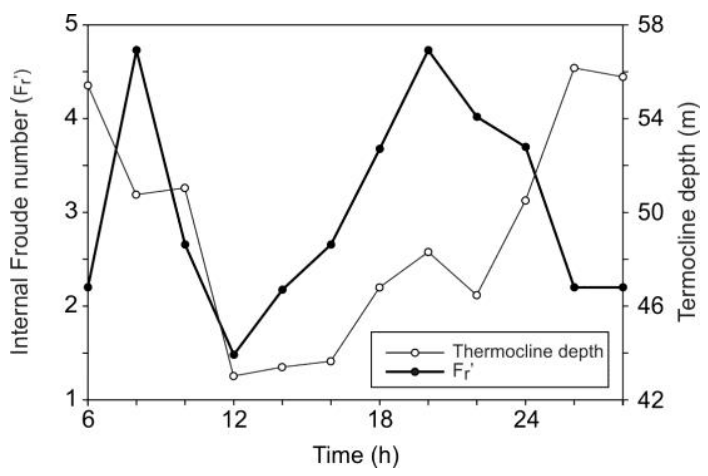

Fig. 5. Internal Froude number (square root of the ratio of the internal force to the buoyancy force), and thermocline depth during the sampling period.

At semidiurnal frequencies, the onshore energy flux (a low-mode convergence) is approximately balanced by the offshore energy flux (a high-wave mode divergence). This conversion occurs in regions where the continental slope is nearly critical with respect to the semidiurnal tide (NASH et al., 2004). On the basis of the results, we computed the slope of the internal wave beam $(r)$ as (MUNROE; LAMB, 2005):

$$
r^{2}=\frac{\omega^{2}-f^{2}}{N^{2}-\omega^{2}}
$$

Where $\omega$ is the wave frequency $\left(\mathbf{M}_{2}\right), f$ the Coriolis frequency, and $N$ the Brunt-Väisälä or buoyancy frequency. The results give $r=0.6$. The ratio of the maximum topography slope to the internal wave beam is 0.2. In this case, the topography is said to be subcritical and all energy propagation is upward (NASH et al., 2004) as low modes. Low modes have more energy, larger group velocities, and weaker shear than their high-mode counterparts; they may propagate across thousands of kilometres from their source before dissipating (CUMMINS et al., 2001). Likewise, turbulent losses in regions of generation of internal tides appear to be weak. Following Munroe and Lamb (2005) to compute the mode-1 internal wave phase speed, we obtained $0.82 \mathrm{~m} \mathrm{~s}^{-1}$, whereas, by means of the classical equation for internal wave phase speed (KNAUSS, 2000), the phase speed was of $0.67 \mathrm{~m} \mathrm{~s}^{-1}$. 
The baroclinic tidal forcing $F$ (BAINES, 1982), computed as a function of time at the sampling point (Fig. 6), shows a dominant value of $30 \times 10^{3}$; this is lower than the range of $40 \times 10^{3}$ to $57 \times 10^{3}$ obtained by Baines at the shelf break, because the slope in our study area is smoother than the one studied by Baines (1982). We obtained a diminution of $F$ at $17 \mathrm{~h}$ and at $2 \mathrm{~h}$, coincident with the high tide.

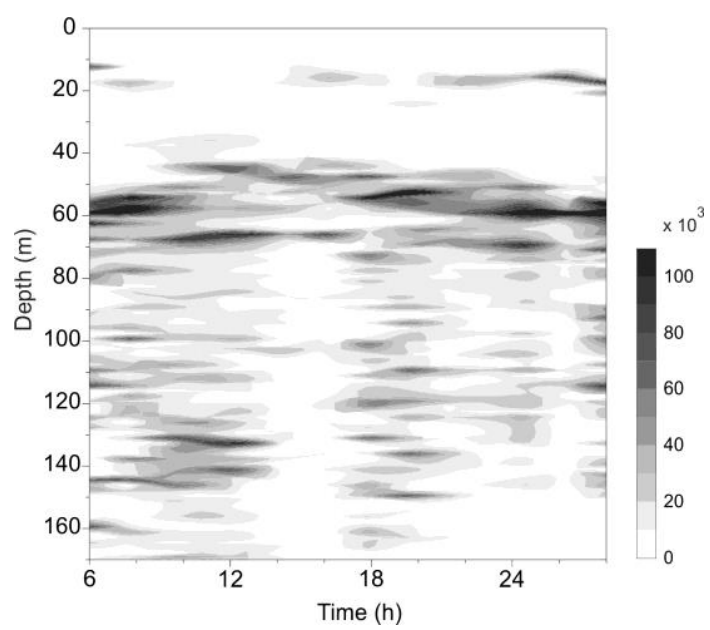

Fig. 6. Baroclinic tidal forcing.

The propagation of internal tides can depress the thermocline by a distance that is comparable to an equivalent depth of (SHERWIN et al., 2002):

$$
E_{d}=\left(\frac{1-h}{D}\right) \times h
$$

Where $E_{d}$ is the equivalent depth or the extent of depression of the thermocline, $h$ is the depth of the thermocline and $D$ is the total depth of the water column. $D$ is $180 \mathrm{~m}$, and the variation of $h$ over time was obtained from Figure $3 \mathrm{a}$. The results show a negative $E_{d}$ evolution (Fig. 7) because $h$ is rising, with the maximum for $E_{d}(10 \mathrm{~m})$ obtained at $12 \mathrm{~h}$, coincidentally with the minimum of the baroclinic tidal forcing, and the high tide, $E_{d}$ attains values of 45 $\mathrm{m}$, while in our region it is of $11 \mathrm{~m}$.

The result of the ROMS simulations was plotted coincidentally with the time of the field observations. Model outputs show lee wave formation where the slope starts to increase sharply. At shallower depths it is possible to see a hydraulic jump (the flow changed from supercritical to subcritical). The temperature and salinity represented by contours in Figure 8a (temperature) and 8b (salinity) show an adjustment to bathymetry, constraining the nearbottom flow to a smaller area. The near-bottom flow, in turn, decelerates because of turbulence and friction.

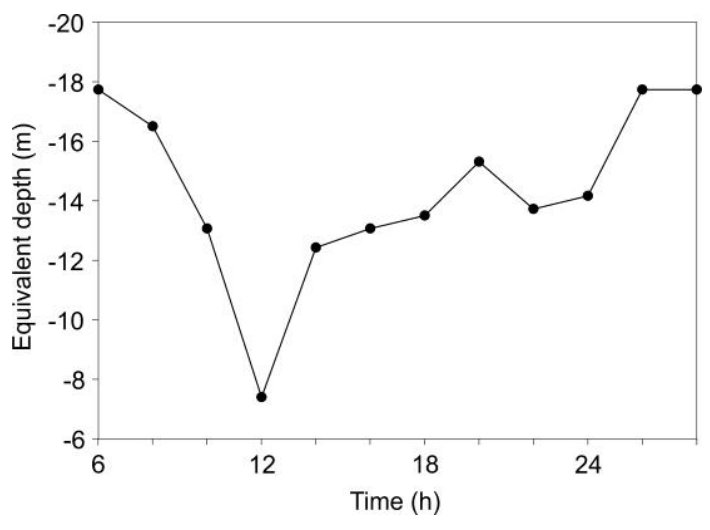

Fig. 7. Equivalent thermocline depth (m).

The abundance and taxa show a $2 \mathrm{~h}$ lag between the relative maximum of the neritic larvae $(10 \mathrm{~h})$ and the oceanic ones $(12 \mathrm{~h})$, the second maximum shows a $4 \mathrm{~h}$ lag between the occurrence of the neritic (20 h) and the oceanic (24 h) (Fig. 9). At 14 $\mathrm{h}$ a great decrease in abundance and total number of larvae and taxa was observed.

It is well known that there is a lag of about $90^{\circ}$ between the maximum height of the tide and the maximum speed of the tidal current (GODIN, 1972). Figure 10 reveals a 4 -h lag between the maximum (or minimum) of the tide and the maximum (or minimum) of larvae and taxa. Delaying the tide height series by 4 $\mathrm{h}$ and plotting it against the total number of larvae and taxa, we found a clear correlation $\left(r^{2}=0.66\right)$ between the tide and the abundance and taxa (Fig. 11). Between $24 \mathrm{~h}$ and $4 \mathrm{~h}$, the zooplankton ascends to the surface of the ocean in response to the low light intensity. Between 20 and $24 \mathrm{~h}$ a marked increase in the total number of larvae and taxa can be observed, but later, there is a decrease that is in phase with the tide. A similar situation is presented between 6 and $12 \mathrm{~h}$, with a maximum in the number of larvae and taxa, when there should be a gradual decrease with the increase of sunlight. So our results seem to be counter-intuitive but they depict the effect of the internal forcing. 

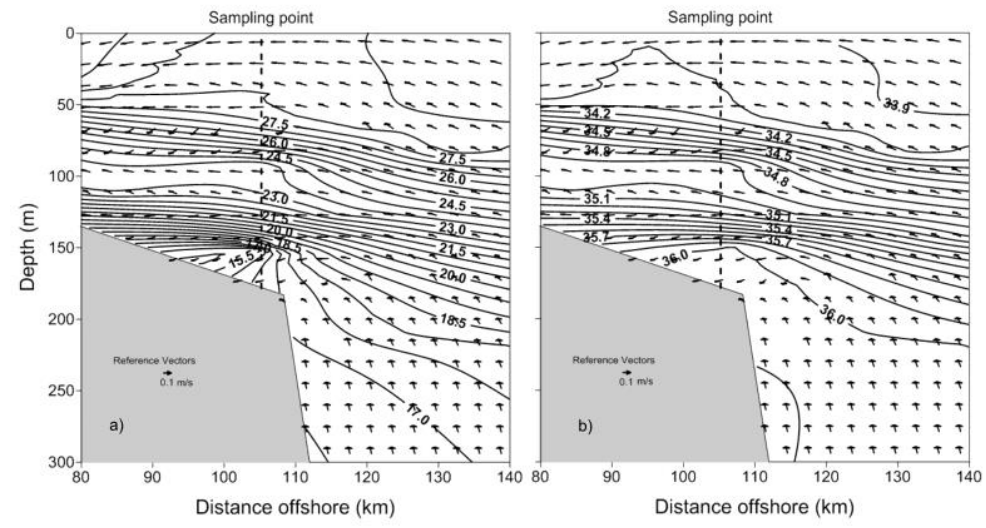

Fig. 8. Model outputs: a) velocities $\left(\mathrm{m} \mathrm{s}^{-1}\right)$ and contours of temperature $\left({ }^{\circ} \mathrm{C}\right)$, and b) velocities $\left(\mathrm{m} \mathrm{s}^{-1}\right)$ and contours of salinities.

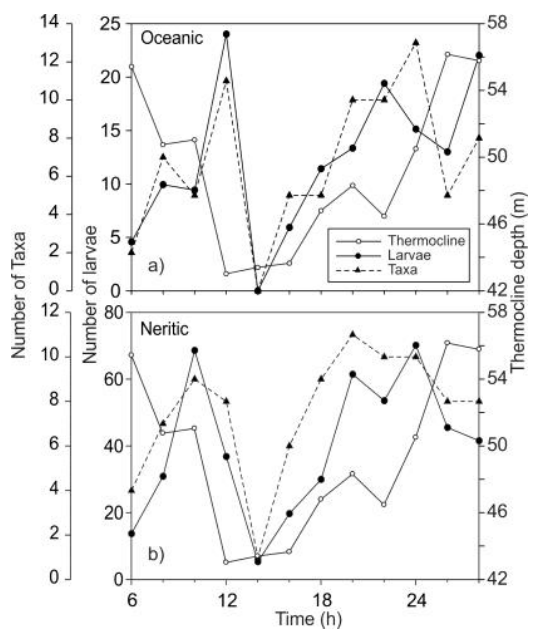

Fig. 9. Total number of oceanic and neritic zooplankton larvae and taxa, and thermocline depth.

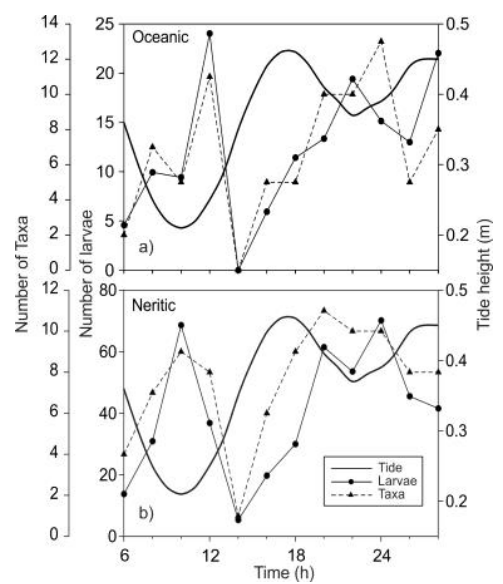

Fig. 10. Total number of oceanic and neritic zooplankton larvae and taxa, and tide height.
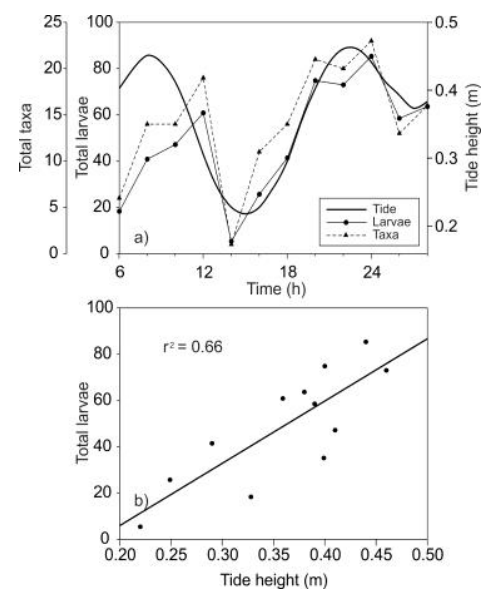

Fig. 11. Total number of larvae and taxa, and tide height lagged by $4 \mathrm{~h}$, and correlation between the tidal height and the total number of larvae.

\section{DiscusSiON}

In this study it was observed that the variation in the composition of the ichthyoplankton is the result of the nonlinear interaction of the barotropic tide with the shelf break. An oversimplified assumption that could contribute to understanding the findings would be that the ascending tide requires mass to form the promontory on the surrounding sea level; this mass is extracted from the surroundings. The tide wave in the sampling region moves almost parallel to the coast (SALAS DE LEÓN; MONREAL GÓMEZ, 1997). The required mass would be pulled from the shallower and deeper areas not from sites of the same depth. During this process, the ichthyoplankton is transported and concentrated by the 
currents, in phase with the tidal current and lags about $90^{\circ}$ with respect to the high tide. During low tide, the mass leaves the region, transporting organisms toward the shallower and deeper surrounding areas. Additionally, the tide induces a semi-hydraulic jump. The internal Froude number was almost always greater than 2, thus the flow was supercritical (SALAS MONREAL et al., 2012). This hydraulic jump is not very well defined (the Froude number continues almost always supercritical), because the tides in this region do not have large ranges (EXPÓSITO DÍAZ et al., 2009), but the hydraulic forcing is enough to raise the isolines and, thereby, contribute to the aggregation and dispersion of plankton in a semidiurnal frequency sequence. The semidiurnal frequencies, the onshore energy flux (a low-mode convergence) is approximately balanced by the offshore energy flux (a high-wave mode divergence) (LODER et al., 1992). This conversion occurs in regions where the continental slope is nearly critical with respect to the semidiurnal tide (NASH et al., 2004). In our case, the topography is said to be subcritical and all energy propagation is upward (NASH et al., 2004) as low modes. As low modes have more energy, larger group velocities, and weaker shear than their high-mode counterparts; they may propagate across thousands of kilometers from their source before dissipating (CUMMINS et al., 2001). Likewise, turbulent losses in regions of generation of internal tides appear to be small.

The baroclinic tidal forcing at the sampling point is lower than the range obtained by Baines (1986) and Sherwin et al. (2002), because the slope in our study area is smoother than the one studied by Baines (1982). We obtained a diminution of the baroclinic tidal forcing coincident with the high tide. Theoretically, at high tide the water speed induced by the barotropic $\mathrm{M}_{2}$ is at the minimum, and the water flux over the shelf break must be minimum also (since the baroclinic tidal forcing has to be in phase with the tidal speed), whereas at the zero tidal level the speed is maximum.

The propagation of internal tides depresses the thermocline (SHERWIN et al., 2002). The results show a negative $E_{d}$ evolution, with the maximum for $E_{d}$ coincident with the minimum of the baroclinic tidal forcing, and the high tide. On the Portuguese shelf, a more energetic region in terms of internal tides, $E_{d}$ reaches values of $45 \mathrm{~m}$ (SHERWIN et al. 2002) while in the study region $E_{d}$ was of $11 \mathrm{~m}$.

The result of the ROMS simulations shows lee wave formation, it is important to note the upward velocities indicating a similar process to the sub superficial upwelling reported by Santiago Arce and Salas de León (2012) in the Campeche Canyon, and Salas Monreal et al. (2012) in the Gulf of California.
The abundance and taxa of the neritic fish larvae showed a 2 to 4 -h lag between the oceanic and neritic larvae that could be due to the fact that, in this region, the oceanic larvae are found in deeper areas than the neritic (ESPINOSA FUENTES; FLORES COTO, 2004) and, hence, take more time to ascend to the region where they were caught. At $14 \mathrm{~h}$ a great decrease in abundance and total number of larvae and taxa was observed, which could be due to the vertical migration that these organisms undergo during the day, but also because of the turbulence induced by the descent of the tide which produces dispersion. In the study area, incident sunlight is strongest from 12 to 17 $\mathrm{h}$, with a maximum at $16 \mathrm{~h}$ (SALAS DE LEÓN et al., 1992). Two hours later, at $18 \mathrm{~h}$, an increment in the total number of larvae can be observed. Thus, the mechanism that produces the decrease in the number of larvae and taxa might not be related solely to sunlight. Forcing must be due to another process and, in this case the ichthyoplankton displacements correlate with the displacement produced by the tide wave when colliding with the shelf. At high tide the rise in the sea level suctions mass, and most probably generates an accumulation of ichthyoplankton, whereas the lowering of the sea level induces dispersion.

It is well known that there is a lag of about $90^{\circ}$ between the maximum height of the tide and the maximum speed of the tidal current. A 4-h lag can be observed between the maximum (or minimum) of the tide and the maximum (or minimum) of larvae and taxa. A similar situation is presented as regards the maximum in the number of larvae and taxa, when there should be a gradual decrease with the increase of sunlight. So our results seem to be counter-intuitive but they depict the effect of the internal forcing.

A common feature reported for some shelf break aggregations is their relationship with vertical currents. Two types of aggregations of organisms have been observed: aggregations of individuals that have lived for a long time ( $>$ weeks) at the same site and ephemeral (< days) accumulations that disperse once the accumulation mechanism ceases to operate (GENIN, 2004). On the basis of this consideration, our study could be dealing with ephemeral accumulations, where aggregations are conditioned by a forcing of the internal tides.

\section{Conclusions}

Pycnocline oscillations with lower amplitude from the shelf break are an evidence of internal tide generation over the slope. The internal tide induced a semi-hydraulic jump formed at the shelf edge by raising the thermocline, halocline, pycnocline, and buoyancy frequency. This process takes place first by mass conservation, and consequently induces 
aggregation of ichthyoplanktonic organisms. The dispersion of water mass during low tide produces dispersion of these organisms. We cannot say whither the organisms are moving; they might be transported toward the coast, i. e. to shallower waters, or toward deeper areas under the shelf edge. In both cases, this may be a mechanism by means of which areas of ichthyoplankton accumulation take place, with rhythms corresponding to those of the tides.

\section{ACKNOWLEDGMENTS}

We wish to thank F. Zavala for his help in collecting and processing samples and the captains, officers and crew of the R/V Justo Sierra of the National Autonomous University of Mexico (UNAM). We also appreciated the assistance of $J$. Castro in drafting the figures. The study was funded by the Instituto de Ciencias del Mar y Limnología of the Universidad Nacional Autónoma de México.

\section{REFERENCES}

ALTHAUS, A. M.; KUNZE, E.; SANFORD, T. B. Internal tide radiation from Mendocino escarpment. J. Phys. Oceanogr., v. 33, n. 7, p. 1510-1527, 2003.

BAINES, P. G. Internal tides, internal waves, and nearinertial motions. In: MOOERS, C. N. K. (Ed.). Baroclinic process on continental shelves. Washington: American Geophysical Union, 1986. p. 19-31. (Coastal and Estuarine Sciences; v. 3).

BAINES, P. G. On internal tide generation models. Deep-Sea Res., Part A, v. 29, n. 3, p. 307-338, 1982.

BERGSTRÖM, B.; STRÖMBERG, J. O. Behavioural differences in relation to pycnoclines during vertical migration of the euphausiids Meganyctiphanes norvegica (M. Sars) and Thysanoessa raschii (M. Sars). J. Plankton Res., v. 19, n. 2, p. 255-261, 1997.

CARTER, G. S.; MERRIFIELD, M. A.; BECKER, J. M.; KATSUMATA, K.; GREGG, M. C.; LUTHER, D. S.; LEVINE, M. D.; BOYD, T. J.; FIRING, Y. L. Energetics of $\mathrm{M}_{2}$ barotropic-to-baroclinic tidal conversion at the Hawaiian Islands. J. Phys. Oceanogr., v. 38, n. 10, p. 2205-2223, 2008.

CUMMINS, P. F.; CHERNIAWSKY, J. Y.; FOREMAN, M. G. G. North Pacific internal tides from the Aleutian Ridge: altimeter observations and modeling. J. Mar. Res., v. 59, n. 2, p. 167-191, 2001.

DOWER, J. F.; BRODEUR, R. D. The role of biophysical coupling in concentrating marine organisms around shallow topographies. J. Mar. Syst., v. 50, n. 1/2, p. 1-2, 2004.

ESPINOSA FUENTES, M. L.; FLORES COTO, C. Crossshelf and vertical structure of ichthyoplankton assemblages in continental shelf waters of the Southern Gulf of Mexico. Estuarine, Coastal Shelf Sci., v. 59, n. 2, p. 333-352, 2004.

EXPÓSITO DÍAZ, G.; SALAS DE LEÓN, D. A.; MONREAL GÓMEZ, M. A.; SALAS MONREAL, D.; VÁZQUEZ GUTIÉRREZ, F. Inertial currents in the southern Gulf of Mexico. Cienc. Mar., v. 35, n. 3, p. 287-296, 2009.

FAHAY, M. P. Guide to the early stages of marine fishes occurring in the Western North Atlantic Ocean, Cape Hatteras to the Southern Scotian SHELF. J. Northwest Atl. Fish. Sci., v. 4, p. 3-423, 1983.

FLORES COTO, C.; MARTÍNEZ GUTIÉRREZ, R.; GONZÁLEZ FÉLIX, M.; SANVICENTE AÑORVE, L.; ZAVALA GARCÍA F. Annual variation of ichthyoplankton assemblages in neritic waters of the southern Gulf of Mexico. Caribb. J. Sci., v. 36, n. 3/4, p. 233-243, 2000.

GENIN, A. Bio-physical coupling in the formation of zooplankton and fish aggregations over abrupt topographies. J. Mar. Syst., v. 50, n. 1/2, p. 3-20, 2004.

GODIN, G. The analysis of tides. Liverpool: Liverpool University Press; Toronto: University of Toronto Press, 1972. 264 p.

GONZÁLEZ POLA, C.; DÍAZ DEL RÍO, G.; RUIZ VILLARREAL, M.; SÁNCHEZ, R. F.; MOHN C. Circulation patterns at Le Danois Bank, an elongated shelf-adjacent seamount in the Bay of Biscay. Deep Sea Res., Part I, v. 60, p. 7-21, 2012.

HEGGELUND, Y.; VIKEB $\square$, F.; BERNTSEN, J.; FURNES G. Hydrostatic and non-hydrostatic studies of gravitational adjustment over a slope. Cont. Shelf Res., v. 24, n. 18, p. 2133-2148, 2004.

HEYWOOD, K. J. Diel vertical migration of zooplankton in the Northeast Atlantic. J. Plankton Res., v. 18, n. 2, p. 163-184, 1996.

HIBIYA, T. Internal wave generation by tidal flow over a continental shelf slope. J. Oceanogr., v. 60, n. 3, p. 637643, 2004.

HILL, R. B.; JOHNSON J. A. A theory of upwelling over the shelf break. J. Phys. Oceanogr., v. 4, n. 1, p. 19-26, 1974.

HOLLOWAY, P. E.; MERRIFIELD M. A. Internal tide generation by seamounts, ridges, and islands. J. Geophys. Res.: Oceans, v. 104, n. C11, p. 25937-25951, 1999.

JOHNSTON, T. M. S.; MERRIFIELD M. A. Internal tide scattering at seamounts, ridges, and islands. J. Geophys. Res.: Oceans, v. 108, n. C11, pt.6, sect.3, p. 1-15, 2003.

JOHNSON, J. A.; ROCKLIFF N. Shelf break circulation processes. In: MOOERS, C. N. K. (Ed.). Baroclinic processes on continental shelves. Washington: American Geophysical Union, 1986. p. 33-62. (Coastal and Estuarine Sciences; v. 3).

KNAUSS, J. A. Introduction to physical oceanography. 2. ed. Upper Saddle River: Prentice Hall, 2000. 309 p.

LAI, Z.; CHEN, C.; COWLES, G. W.; BEARDSLEY, R. C. A nonhydrostatic version of FVCOM: 1. Validation experiments. J. Geophys. Res.: Oceans, p. 115, n. C11, p. 1-23, 2010.

LENNERT CODY, C. E.; FRANKS, P. J. S. Fluorescence patches in high-frequency internal waves. Mar. Ecol.: Prog. Ser., v. 235, p. 29-42, 2002.

LENNERT CODY, C. E.; FRANKS P. J. S. Plankton patchiness in high-frequency internal waves. Mar. Ecol.: Prog. Ser., v. 186, p. 59-66, 1999.

LODER, J. W.; BRICKMAN, D.; HORNE, E. P. W. Detailed structure of currents and hydrography on the northern side Georges Bank. J. Geophys. Res.: Oceans, v. 97, n. C9, p. 14331-14351, 1992. 
MONREAL GÓMEZ, M. A.; SALAS DE LEÓN, D. A.; PADILLA PILOTZE, A. R.; ALATORRE MENDIETA M. A. Hydrography and estimation of density currents in the southern part of the Bay of Campeche, Mexico. Cienc. Mar., v. 18, n. 4, p. 115-133, 1992.

MOORE, A. M.; ARANGO, H. G.; DI LORENZO, E.; CORNUELLE, B. D.; MILLER, A. J.; NEILSON D. J. A. Comprehensive ocean prediction and analysis system based on the tangent linear and adjoint of a regional ocean model. Ocean Modell., v. 7, n. 1/2, p. 227-258, 2004.

MUNROE, J. R.; LAMB K. G. Topographic amplitude dependence of internal wave generation by tidal forcing over idealized three-dimensional topography. $\mathbf{J}$. Geophys. Res.: Oceans, v. 110, n. C02, p. 1-14, 2005.

NASH, J. D.; KUNZE, E.; TOOLE, J. M.; SCHMITT, R. W. Internal tide reflection and turbulent mixing on the continental slope. J. Phys. Oceanogr., v. 34, n. 5, p. 1117-1134, 2004.

OEY, L. Y.; EZER, T.; MIYAZAWA, Y.; WU C. R. Editorial-International Workshop on Modeling the Ocean (IWMO) special issue in Ocean Dynamics. Ocean Dyn., v. 60 , n. 2, p. 299-300, 2010.

PICHON, A.; MOREL, Y. BARAILLE, R.; QUARESMA L. $S$. Internal tide interactions in the Bay of Biscay: Observations and modelling. J. Mar. Syst., v. 109-110, p. 526-544, 2013.

PINEDA, J. circulation and larval distribution in internal tidal bore warm fronts. Limnol. Oceanogr., v. 44, n. 6, p. 1400-1414, 1999.

PIONTKOVSKI, S. A.; WILLIAMS, R.; PETERSON, W. T.; YUNEV, O. A.; MINKINA, N. I.; VLADIMIRON, V. L.; BLINKOV A. Spatial heterogeneity of the planktonic fields in the upper mixed layer of the open ocean. Mar. Ecol.: Prog. Ser., v. 148, p. 145-154, 1997.

RYAN, J. P.; CHAVEZ, F. P.; BELLINGHAM J. G. Physical-biological coupling in Monterey Bay, California: topographic influences on phytoplankton ecology. Mar. Ecol. Prog. Ser., v. 287, p. 23-32, 2005.

ROBERTSON, R. Modeling internal tides over Fieberling Guyot: resolution, parameterization, performance. Ocean Dyn., v. 56, n. 5/6, p. 430-444, 2006.

RUBENSTEIN, D. Observations of cnoidal internal waves and their effect on acoustic propagation in shallow water. IEEE J. Oceanic Eng., v. 24, n. 3, p. 346-357, 1999.

SALAS DE LEÓN, D. A.; MONREAL GÓMEZ, M. A.; SANVICENTE AÑORVE, L.; FLORES COTO, C. Influence de la circulation à long terme sur la répartition des organismes zooplanctoniques dans la Baie de Campeche, Mexique. Oceanol. Acta, v. 21, n. 1, p. 87 93, 1998.

SALAS DE LEÓN, D. A.; MONREAL GÓMEZ, M. A. Mareas y circulación residual en el Golfo de México. In: LAVÍN-PEREGRINA, M. F. (Ed.). Contribuciones a la oceanografía física en México. México: Unión Geofísica Mexicana, 1997, p. 201-223. (Monografía; n. $3)$.

SALAS DE LEÓN, D. A.; MONREAL GÓMEZ, M. A.; ALDECO RAMÍREZ A. Períodos característicos en las oscilaciones de parámetros meteorológicos en Cayo Arcas, México. Atmosfera, v. 5, n. 4, p. 193-205, 1992.

SALAS DE LEÓN, D. A.; DÍAZ FLORES, M. A.; MONREAL GÓMEZ M. A. Circulation and vorticity in the Southern Gulf of Mxico. In: SCHRÖDER, W. (Ed.).
Hans Ertel memorial book. Vienna: German Commission on history of Geophysics and Cosmical Physics, 2004. p. 229-243.

SALAS DE LEÓN, D. A.; CARBAJAL, N.; MONREAL GÓMEZ, M. A.; GIL ZURITA, A. Vorticity and mixing induced by the barotropic $M_{2}$ tidal current and zooplankton biomass distribution in the Gulf of California. J. Sea Res., v. 66, n. 2, p. 143-153, 2011.

SALAS MONREAL, D.; SALAS DE LEÓN, D. A.; MONREAL GÓMEZ, M. A.; RIVERÓN ENZÁSTIGA, M. L.; MOJICA RAMÍREZ, E. Hydraulic jump in the Gulf of California. Open J. Mar. Sci., v. 2, p. 141-149, 2012.

SANGRÁ INCIARTE, P.; BASTERRETXEA OYARZABAL, G.; PELEGRÍ LLOPART, J. L.; ARÍSTEGUI RUIZ, J. Chlorophyll increase due to internal waves on the shelf break of Gran Canaria (Canary Islands). Sci. Mar., v. 65, suppl. 1, p. 89-97, 2001.

SANTIAGO ARCE, T.; SALAS DE LEÓN, D. A. Vorticity and internal waves in the Campeche Canyon, Gulf of Mexico. In: KLAPP, J.; CROS, A.; VELASCOFUENTES, O.; STERN, C.; RODRÍGUEZ-MEZA, M.A. (Eds.). Experimental and theoretical advances in fluid dynamics. Berlin: Heidelberg, Springer-Verlag, 2012. p. 163-170. (Environmental Science and Engineering).

SHANKS, A. L. Surface slicks associated with tidally forced internal waves may transport pelagic larvae of benthic invertebrates and fishes shoreward. Mar. Ecol.: Prog. Ser., v. 13, p. 311-315, 1983.

SHERWIN, T. J.; VLASENKO, V. I.; STASHCHUK, N.; JEANS, D. R. G.; JONES, B. Along-slope generation as an explanation for some unusually large internal tides. Deep Sea Res., Part I, v. 49, n. 10, p. 1787-1799, 2002.

VALLE LEVINSON, A.; TRASVINA CASTRO, A.; GUTIERREZ DE VELASCO, G.; GONZALEZ ARMAS, R. Diurnal vertical motions over a seamount of the southern Gulf of California. J. Mar. Syst., v. 50, n. $1 / 2$, p. 61-77, 2004.

WALSH, J. J.; WEISBERG, R. H.; DIETERLE, D. A.; HE, R.; DARROW, B. P.; JOLLIFF, J. K.; LESTER, K. M.; VARGO, G. A.; KIRKPATRICK, G. J.; FANNING, K. A.; SUTTON, T. T.; JOCHENS, A. E.; BIGGS, D. C.; NABABAN, B.; HU, C.; MULLER-KARGER, F. E. Phytoplankton response to intrusions of slope water on the West Florida shelf: models and observations. J. Geophys. Res., v. 108, n. C6, p. 1-23, 2003.

YÁÑEZ ARANCIBIA, A.; SÁNCHEZ-GIL, P. Los peces demersales de la plataforma continental del sur del Golfo de México: caracterización ambiental, ecología y evaluación de las especies, poblaciones y comunidades. México: Instituto de Ciencias del Mar y Limnología, Universidad Nacional Autónoma del Mexico, 1986. 229 p.

ZELDIS, J. R.; JILLETT J. B. Aggregation of pelagic Munida gregaria (Fabricius) (Decapoda, Anomura) by coastal fronts and internal waves. J. Plankton Res., v. 4, n. 4, p. 839-857, 1982.

(Manuscript received 31 January 2013; revised 23 September 2013; accepted 07 November 2013) 